\title{
PENTINGNYA PERAN PERAWAT DALAM MENERAPKAN K3 DI RUMAH SAKIT
}

\author{
JIHAN ASYLA \\ jihanasyla20@gmail.com
}

\begin{abstract}
ABSTRAK
Saat ini perawat memiliki peran yang lebih luas dengan penekanan pada peningkatan kesehatan serta pencegahan penyakit, dan memandang klien secara komprehensif dan adil. Perawat menjalankan fUngsi yang kaitannya dengan berbagai peran pemberi perawatan, pembuat keputusan klinik dan etika, pelindung dan advokat bagi klien, manajer kasus, rehabilitator serta komunikator. Pelaksanaan Kesehatan dan Keselamatan $\mathrm{Ke}^{\wedge} \mathrm{a}(\mathrm{K} 3)$ adalah salah satu bentuk upaya untuk menciptakan tempat $\mathrm{ke}^{\wedge} \mathrm{a}$ yang aman, nyaman, sehat, bebas dari pencemaran lingkungan, yang mana akan dapat mengurangi atau bebas dari kecelakaan kerja serta penyakit akibat kerja yang pada akhirnya dapat meningkatkan efisiensi dan produktivitas $\mathrm{ke}^{\wedge} \mathrm{a}$. Kecelakaan $\mathrm{ke}^{\wedge} \mathrm{a}$ tidak saja menimbulkan korban jiwa maupun kerugian materi bagi pekerja dan rumah sakit, tetapi juga dapat mengganggu proses pelayanan secara menyeluruh, merusak lingkungan, dan pada akhirnya akan berdampak pada masyarakat luas.
\end{abstract}

KATA KUNCI : Kesehatan, Keselamatan, Rumah Sakit. 


\section{LATAR BELAKANG}

Perawat adalah suatu profesi yang mulia, karena memerlukan kesabaran serta ketenangan dalam melayani pasien yang sedang menderita sakit. Sebagai seorang perawat harus dapat memahami masalah yang dihadapi oleh klien, selain itu seorang perawat juga harus berpenampilan rapi dan menarik. Untuk itu seorang perawat memerlukan kemampuan untuk memperhatikan orang lain, keterampilan intelektual, teknikal dan interpersonal juga harus tercermin dalam perilaku perawat.

Saat ini perawat memiliki peran yang lebih luas dengan penekanan pada peningkatan kesehatan serta pencegahan penyakit, dan memandang klien secara komprehensif dan adil. Perawat menjalankan fungsi yang kaitannya dengan berbagai peran pemberi perawatan, pembuat keputusan klinik dan etika, pelindung dan advokat bagi klien, manajer kasus, rehabilitator serta komunikator.

Pelaksanaan Kesehatan dan

Keselamatan $\mathrm{Ke}^{\wedge} \mathrm{a}(\mathrm{K} 3)$ adalah salah satu bentuk upaya untuk menciptakan tempat $\mathrm{ke}^{\wedge} \mathrm{a}$ yang aman, nyaman, sehat, bebas dari pencemaran lingkungan, yang mana akan dapat mengurangi atau bebas dari kecelakaan $\mathrm{ke}^{\wedge} \mathrm{a}$ serta penyakit akibat $\mathrm{ke}^{\wedge} \mathrm{a}$ yang pada akhirnya dapat meningkatkan efisiensi dan produktivitas $\mathrm{ke}^{\wedge} \mathrm{a}$. Kecelakaan $\mathrm{ke}^{\wedge} \mathrm{a}$ tidak saja menimbulkan korban jiwa maupun kerugian materi bagi pekerja dan rumah sakit, tetapi juga dapat mengganggu proses pelayanan secara menyeluruh, merusak lingkungan, dan pada akhirnya akan berdampak pada masyarakat luas.

Penyakit Akibat Keija (PAK) dan Kecelakaan Kerja (KK) di kalangan petugas kesehatan dan non kesehatan kesehatan di Indonesia belum terekam dan teratasi dengan baik. Sebagai faktor penyebab, kecelakaan sering terjadi karena kurangnya kesadaran pekerja dan kualitas serta keterampilan pekerja yang kurang memadai. Banyak pekerja yang meremehkan risiko kerja, sehingga jarang menggunakan alat- alat pengaman walaupun sudah tersedia.

\section{TUJUAN}

Tujuan kajian ini dibuat adalah untuk mengetahui pentingnya perawat menguasai K3 di rumah sakit.

\section{METODE}

Penulisan ini dilakukan menggunakan metode kajian bebas terhadap pokok bahasan yang dikumpulkan dari beberapa sumber yang berkaitan dengan pokok bahasan. 


\section{HASIL}

Berdasarkan hasil analisis dan kajian bebas pada beberapa jumal yang sesuai dengan topik yang dibahas, maka dapat diperoleh bahwa perawat harus mengetahui fungsi dan peran seorang perawat serta disarankan berkeija dengan memperhatikan fungsi dan perannya tersebut. Kesehatan dan keselamatan keija sangat penting dal am pembangunan karena sakit dan kecelakaan keija akan menimbulkan kerugian ekonomi (lost benefit) rumahsakit olehnya itu kesehatan dan keselamatan keija harus dikelola secara maksimal bukan saja oleh tenaga kesehatan tetapi seluruh SDM di lingkungan tersebut.

\section{PEMBAHASAN}

Keselamatan dan kesehatan keij a diartikan sebagai suatu pemikiran dan upaya untuk menjamin keutuhan dan kesempurnaan baik jasmani maupun rohani si tenaga keija pada khususnya dan manusia pada umumnya, hasil karya dan budayanya menuju masyarakat makmur dan sejahtera. Sedangkan pengertian secara keilmuan adalah suatu ilmu pengetahuan dan penerapannya digunakan dal am usaha mencegah kemungkinan teij adinya kecelakaan dan penyakit akibat keija.

Dalam Undang-Undang No.23 Tahun 2003 tentang Kesehatan, Pasal 23 dinyatakan bahwa upaya Kesehatan dan Keselamatan Keija (K3) harus di s elenggarakan di semua tempat kerja, khususnya tempat keija yang memiliki resiko bahaya kesehatan, mudah teijangkit penyakit atau mempunyai karyawan yang paling sedikit beranggotakan 10 orang. Jika memperhatikan isi dari pasal di atas maka jelas bahwa Rumah Sakit (RS) termasuk ke dalam kriteria tempat keija dengan berbagai ancaman bahaya yang dapat menimbulkan dampak kesehatan, tidak hanya terhadap para pelaku langsung yang bekeija di RS, tapi juga terhadap pasien maupun pengunjung yang terdapat di RS. Sehingga sudah seharusnya pihak pengelola RS menerapkan upaya-upaya untuk meningkatkan K3 di RS.

Potensi bahaya di RS, selain berbagai macam infeksi juga ada potensi berbagai macam bahaya laiin yang mempengaruhi situasi dan kondisi di RS, yaitu kecelakaan (peledakan, kebakaran, kecelakaan yang berhubungan dengan instalasi listrik, dan sumber-sumber cidera lainnya), radiasi, bahan-bahan kimia yang berbahaya, gas-gas anastesi, gangguan psikososial serta ergonomi. Semua potensi 
bahaya tersebut jelas mengancam jiwa dan kehidupan bagi para SDM di RS.

Tenaga Kesehatan adalah setiap orang yang mengabdikan dirinya dal am bidang kesehatan serta memiliki pengetahuan dan keterampilan melalui pendidikan di bidang kesehatan yang untuk $\mathrm{j}$ enis tertentu memerlukan kewenangan untuk melakukan upaya kesehatan, baik berupa pendidikan gel ar D3, SI, S2, S3, pendidikan non gelar, sampai dengan pelatihan khusus untuk kejuruan khusus seperti Juru Imunisasi, Malaria, dsb, dan keahlian. Hal inilah yang membedakan jenis tenaga ini dengan tenaga lainnya. Hanya mereka yang mempunyai pendidikan atau keahlian khusus yang boleh melakukan pekeijaan tertentu yang berhubungan dengan jiwa dan fisik manusia, serta lingkungannya. Dalam hal ini, perawat memegang peranan yang cukup besar dalam upaya pelaksanaan dan peningkatan K3 di rumah sakit. Dalam pelaksanaannya perawat tidak dapat bekeija secara individual, perawat perlu untuk berkolaborasi dengan profesi tenaga kesehatan lainnya maupun SDM lainnya di RS.

Fungsi seorang perawat sangat tergantung kepada kebij aksanaan rumah sakit dalam hal luasnya ruang lingkup usaha kesehatan, susunan dan jumlah tenaga kesehatan yang dipekeijakan dalam rumah sakit. Perawat merupakan satu-satunya tenaga kesehatan yang full time berada di rumah sakit, maka fungsinya diantaranya adalah memelihara dan mempertinggi mutu pelayanan perawatan, membantu dokter dalam pemeriksaan kesehatan sesuai cara- cara yang tel ah disetujui, ikut membantu menentukan kasus-kasus penderita, serta berusaha meni ndaklanjuti sesuai wewenang yang diberikan kepadanya, membantu usaha perbaikan kesehatan lingkungan dan rumah sakit sesuai kemampuan yang ada, turut ambil bagian dalam usaha keselamatan keij a, mengumpulkan data-data dan membuat laporan untuk statistic dan evaluasi, turut membantu dalam usaha penyelidikan kesehatan tenaga keij a, memelihara hubungan yang harmonis dalam rumah sakit, memberikan penyuluhan dalam bidang kesehatan, dll.

Perawat waj ib mengetahui fungsi dan peran seorang perawat dan disarankan bekeija dengan memperhatikan fungsi dan perannya tersebut. Kesehatan dan keselamatan keija sangat penting diterapkan karena jika teijadi akan menimbulkan kerugian ekonomi yang tentunya tidak diinginkan. Oleh karena itu kesehatan dan keselamatan keija harus dikelola secara 
maksimal bukan saja oleh tenaga kesehatan tetapi seluruh masyarakat.

\section{KESIMPULAN}

Perawat adalah suatu profesi yang mulia, karena memerlukan kesabaran serta ketenangan dalam melayani pasien yang sedang menderita sakit. Sebagai seorang perawat harus dapat memahami masalah yang dihadapi oleh klien, selain itu seorang perawat juga harus berpenampilan rapi dan menarik. Untuk itu seorang perawat memerlukan kemampuan untuk memperhatikan orang lain, keterampilan intelektual, teknikal dan interpersonal juga harus tercermin dalam perilaku perawat.

Kesehatan keija adalah spesialisasi dalam ilmu kesehatan beserta prakteknya yang bertujuan agar pekerj a/masyarakat memperoleh derajat kesehatan yang setinggi-tingginya, baik fisik, atau mental, serta sosial, dengan usaha-usaha preventif dan kuratif, terhadap berbagai penyakit/ berbagai gangguan kesehatan yang diakibatkan oleh faktor-faktor pekerjaan dan lingkungan kerja, serta terhadap penyakit- penyakit umum.

\section{DAFTAR PUSTAKA}

Darlian, D. (2016). Hubungan Pengetahuan Perawat dengan Upaya Penerapan Patient Safety di Ruang Rawat Inap
RSUD Dr. Zainoel Abidin Banda Aceh.Ideal Nursing Journal, Vol 7, No. 1, Hal. 61-69

Edisi Multi Profesional. (2015). Panduan Kurikulum Keselamatan

Pasien.Jakarta : Lembaga Kesehatan Budi Kemuliaan

Firawati, dkk.(Maret 2012).Pelaksanaan Program Keselamatan Pasien di Rumah Sakit Solok.Jurnal Kesehatan

Masyarakat, Vol. 6, No. 2, Hal. 74-75

Harus, B.D., dkk. (2015). Pengetahuan

Perawat Tentang Keselamatan Pasien dengan Pelaksanaan Prosedur

Keselamatan Pasien Rumah Sakit (KPRs) di Rumah Sakit Panti Waluya Sawahan Malang.Jurnal Care, Vol. 3, No. 1, Hal. 25-26

Islami, K., dkk. (2018). Analisis Pelaksanaan Program Keselamatan Pasien Puskesmas Mangkang, Kota Semarang. Jurnal Kesehatan Masyarakat, Vol. 6, No. 4, Hal. 2741

Ismainar, H. (2019^. Keselamatan Pasien di Rumah Sakit. Yogyakarta: Deepublish

Isnaini, N.M., ～\& Rofii, M. (Mei 2014).Pengalaman Perawat Pelaksana dalam Menerapkan 
Keselamatan Pasien. Jurnal

Managemen Keperawatan, Vol. 2, No.

1, Hal. 31

Nivalinda, D., dkk. (November 2013).

Pengaruh Motivasi Perawat dan Gaya

Kepemimpinan Kepala Ruang

Terhadap Penerapan Budaya

Keselamatan Pasien Oleh Perawat

Pelaksana Pada Rumah Sakit

Pemerintah di S emarang. Jurnal

Managemen Keperawatan, Vol. 1, No.

2, Hal. 139

Putri, S., Santoso, S., \& Rahayu, E. P. (2018).Pelaksanaan Keselamatan

Pasien dan Kesehatan Kerja terhadap

Kejadian Kecelakaan Kerja Perawat

Rumah Sakit.Jurnal Endurance:

Kajian Ilmiah Problema Kesehatan, 3(2), 271-277

R.H Simamora. (20119). Buku Ajar

Pelaksanaan identifikasi

pasien.Uwais inspirasi Indonesia.

R.H Simamora. (2019). Documentation Of

Patient Identification Into The

Electronic System To Improve The

Quality Of Nursing Services.

International Journal Of Scientific \&

Technology Research

R.H Simamora. (2019). Pengaruh Penyuluhan
Identifikasi Pasien

dengan Menggunakan Media

Audiovisual terhadap Pengetahuan

Pasien Rawat Inap

Rizara, A. dkk.(2017). Analisis Pelaksanaan Tujuh Langkah Menuju Keselamatan Pasien di Rumah Sakit Islam Sultan Agung Semarang. Jurnal Kesehatan Masyarakat, Vol. 5, No. 1, Hal. 1-8

Sakinah, S., dkk.(Oktober 2017).Analisis Sasaran Keselamatan Pasien Dilihat dari Aspek Pelaksanaan Identifikasi Pasien dan Keamanan Obat di RS Kepresidenan RSPAD Gatot Subroto J akarta.Jurnal Kesehatan Masyarakat (e-journal), Vol 5, No4. Hal. 145

W ardhani, V. (2017)+Mana/emen Keselamatan Pasien. Malang : UB Press

Yasmi, Y., \& Thabrany, H. (2018).Faktor- F aktor yang Berhubungan dengan Keselamatan Pasien di Rumah Sakit Karya Bhakti Pratiwi Bogor Tahun 2015. Jurnal Administrasi Rumah Sakit, Vol. 4, No. 2, Hal. 98-109

Yulia, S., dkk. (November 2012). Peningkatan perawat Pelaksana dalam Penerapan Keselamatan Pasien Melalui Pelatihan 
Keselamatan Pasien.Jurnal

Keperawatan Indonesia, Vol. 15,

No.3, Hal. 187-189 